\title{
Adverse Event Body System or Organ Class
}

National Cancer Institute

\section{Source}

National Cancer Institute. Adverse Event Body System or Organ Class. NCI Thesaurus.

Code C83197.

The body system or organ class affected by an adverse event. 